\title{
Ground stone percussion tools from Maltese Islands
}

\author{
Felice Larocca
}

Università degli Studi di Bari Aldo Moro, Gruppo di ricerca speleo-archeologica, Piazza Umberto I n. 1, 70121, Bari, Italy. and Centro Regionale di Speleologia "Enzo dei Medici”, Via Lucania n. 3, 87070 Roseto Capo

Spulico, Cosenza, Italy. Email: specus@tin.it; felicelarocca1964@gmail.com

\begin{abstract}
:
A few lithic percussion tools, probably related to construction and craftsmanship, are stored in the National Museum of Archaeology of Valletta (Malta). Dated to the Temple Period (about 40002500 BCE), many are typologically similar to artefacts from the continental area, but others look distinctive and probably developed in loco in response to specific needs. This paper examines five stone hammers with different hafting methods (three of them show grooves or holes and two both grooves and holes). A huge double hand grip percussion tool belongs to a different and unusual typology: the double grip allowed two opposite-standing men, steadily holding it, to strike with strength on other surfaces, probably when heavy blows were needed. Grooved stone hammers are widespread in various European regions and are mostly associated with mining activities. In the Maltese archipelago the limestone lacks ore deposits, and thus their presence may be reflect other uses, although still associated to the work of stone on stone: earthworks, quarrying, finishing of stone surfaces, hydraulic works, excavation of burial and rituals structures, and others. The double grip lithic percussor (ID 9120) has no precise parallel and may be unique. This paper aims to fill a gap in the current literature about prehistoric lithic tools, as in many studies the focus is often placed on the results of specific activities rather than on the typological features of the artefacts that made these activities possible.
\end{abstract}

Keywords: Malta; prehistory; Temple Period; ground stone tools; percussor

\section{Introduction}

The National Museum of Archaeology in Valletta holds some ground stone percussion tools dating to the Temple Period (c. 4000-2500 BCE) (Sultana 2006). The first group of these tools shows typological features linked to similar artefacts from the continent, while the other group shows peculiar features that allow us to hypothesize that these tools developed in loco to meet specific requirements.

The first group includes hammers characterized by a wide and deep groove on the body, suitable for a wooden handle. This is a rather widespread class of tools in other geographic areas, in Europe as well as other continents, though in the Maltese Archipelago this class also shows unusual elements, such as the presence of a hole - from side to side of the tool - within the groove. Within the second group of tools there is a large striker (to my knowledge, an unparalleled tool outside Malta), provided with a double handle so that two opposing people

Published by the School of History, Classics and Archaeology, University of Edinburgh ISSN: 2055-0472. URL: http://journals.ed.ac.uk/lithicstudies/

This work is licensed under a Creative Commons Attribution 2.5 UK: Scotland License. 
held it in order to deliver extremely powerful blows to another surface or object. Unfortunately, these artefacts were not found in clear stratigraphic sequences, and thus can be dated only roughly, based on their general context.

Due to the absence of any precise information collected at the time of discovery, we can date these implements using their association to the archaeological site where they were found, whose time span dates them at the $4^{\text {th }}-3^{\text {rd }}$ millennium BCE. Nevertheless, it is important to report their presence in the Maltese Islands to identify the diffusion of ground stone percussion tools in the Mediterranean basin.

Their presence and dating to the period of the Temples comes as no surprise. This phase of Maltese prehistory is characterized by the construction of impressive monumental structures, some open-air (especially the large megalithic sacred structures) and others subterranean (burial or cultic structures, but also hydraulic works). All of these structures require a varied and specialized tool kit, often composed of heavy implements that would fit the different needs of the artisan in the execution of their work. For several reasons (mainly the sporadic nature of the finds but also the lack of a precise documentation of the excavation), it is difficult to find clear relationships between these instruments and specific products (architectural or others), but it is clear that the artefacts analysed in this paper represent the reflection of the great - and yet still not fully explained - ability of Maltese prehistoric people to produce extraordinary monumental structures, which are among the most important in the Mediterranean area.

\section{Materials and methods}

Five tools are discussed in this paper. They are from Malta Island, the largest of Maltese Islands. Three are from Tarxien, $2 \mathrm{~km}$ south of the Grand Harbour (the great natural creek overlooking the capital city of Valletta), whilst two are from the territory of Mnajdra, on the southwestern coast. Observations are solely macroscopic because they were carried out in the museum where no technical equipment was available. General information and brief descriptions of these tools are summarized below.

\section{Results}

\section{Tool ID 9120}

- Typology: lithic percussor with double grip.

- Context: Tarxien Temples.

- Size: length $28.3 \mathrm{~cm}$; width $23.3 \mathrm{~cm}$; maximum thickness $11.95 \mathrm{~cm}$.

- Weight: $>5000 \mathrm{~g}$.

- Preservation: whole (except for a single large chip).

- Description: (See Figure 1.) The artefact is made of a very light-coloured limestone rich in micro-fossils. Its general shape resembles a rectangular parallelepiped with six openings on four main faces arranged around a central axis. These openings are ovoid and have an average measure of $10.5 \times 6.0 \mathrm{~cm}$; they form a system of opposite handles that allows two people facing each other to grab the tool. A fine polish can be observed near the handles, which diffuses across most of the tool. This is both because of the manufacturing process of the first surface and the prolonged use-wear. The opposite end shows a different profile, round on one side and completely flat on the other. Chipping fractures located on the round portion suggest that the artefact was subjected to major impact on this side, suggesting it was used for both direct and indirect percussion. Size and weight suggest a specific function: to strike strong blows on other surfaces or materials. 


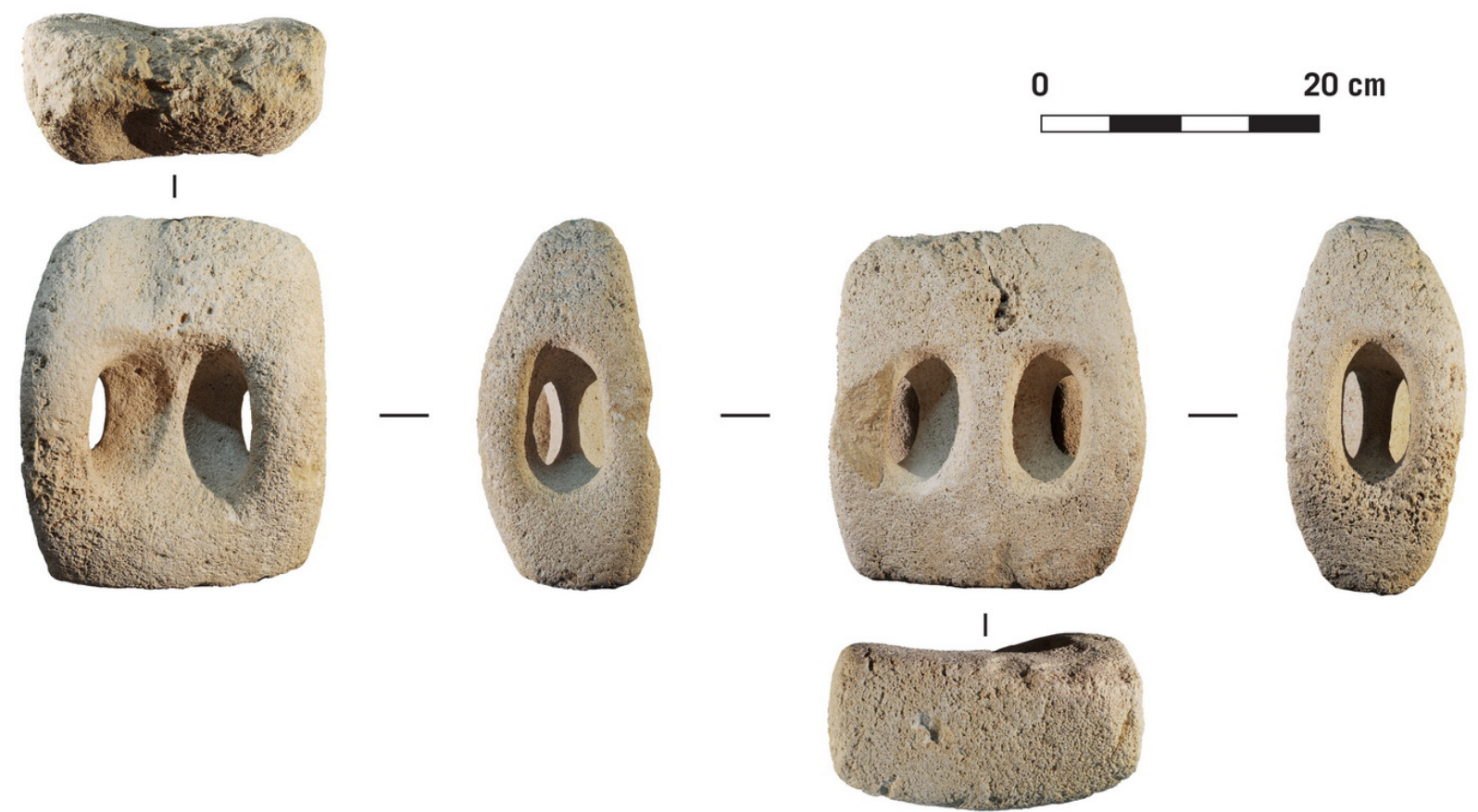

Figure 1. Lithic double-handled artefact ID 9120 used to deliver strong blows, observed in six different views. The tool was held by two opposing people and probably had a remarkable power of impact.

\section{Tool ID 21149}

- Typology: lithic hammerstone.

- Context: Mnajdra.

- Size: length $15.2 \mathrm{~cm}$; width $7.95 \mathrm{~cm}$; maximum thickness $7.8 \mathrm{~cm}$.

- Weight: 1445 g.

- Preservation: whole.

- Description: (See Figure 2.) The artefact is made of a very light-coloured limestone rich in micro-fossils. Typologically it fits the hammerstone category with a continuous groove on the middle part of the lithic body which shows a perforation within it. The groove is irregular, about $2.8 \mathrm{~cm}$ large and $0.6 \mathrm{~cm}$ deep. The hole is $5.4 \mathrm{~cm}$ deep and shows a typical biconical "hourglass" section that suggests the use of a rudimentary drill. The presence of the groove and perforation suggests it was handled in a more complex way than those tools in which either the groove or the perforation is present. Both extremities of the artefact have a clearly rounded profile and display several pecking marks all over the surface.

\section{Tool ID 21136}

- Typology: lithic hammerstone.

- Context: Mnajdra.

- Size: length $13.1 \mathrm{~cm}$; width $7.8 \mathrm{~cm}$; maximum thickness $7.7 \mathrm{~cm}$.

- Weight: 1250 g.

- Preservation: whole.

- Description: (See Figure 3.) This artefact is very similar to the tool ID 21149, though it is smaller and shows a more careful finish; it has a continuous groove over the body and differs from ID 21149 because it shows a circular depression in lieu of the perforation within the groove. The groove width is quite regular $(2.4 \mathrm{~cm})$ as is the depth $(0.75 \mathrm{~cm})$. The depression has an average measure of $3.75 \times 3.2 \mathrm{~cm}$ and is $1.1 \mathrm{~cm}$ deep. Made of a light-coloured limestone, it shows a widespread, slightly coarse polish that spares only the surroundings of the working surfaces. These surfaces have a clear round profile. The hammerstone shape of 
this tool is very balanced giving a symmetrical aspect to each of its parts. In transversal section it is sub-circular tending to slightly sub-quadrangular closer to the groove.
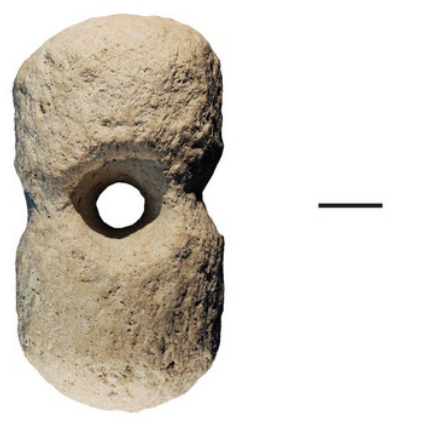

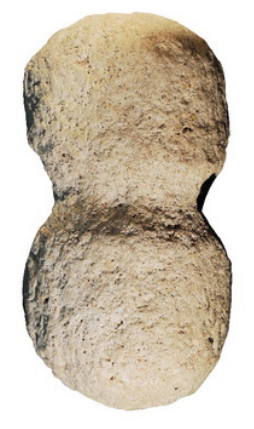

0
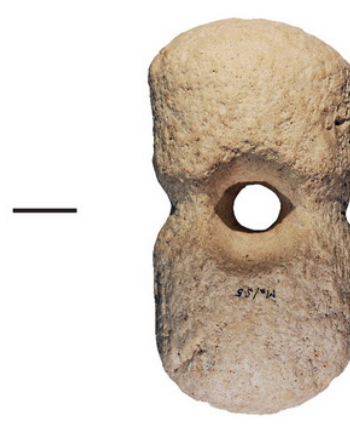

$15 \mathrm{~cm}$

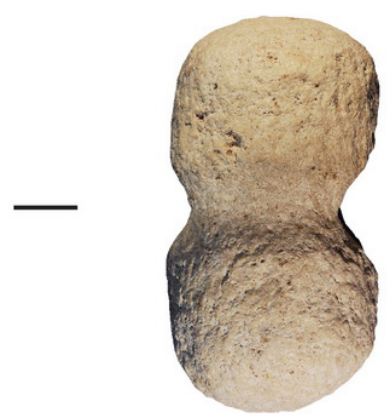

Figure 2. Lithic hammerstone ID 21149 observed in four different views. Its peculiarity is the joined presence of both the groove and the perforation realized within the groove itself; they were both functional to the hafting.

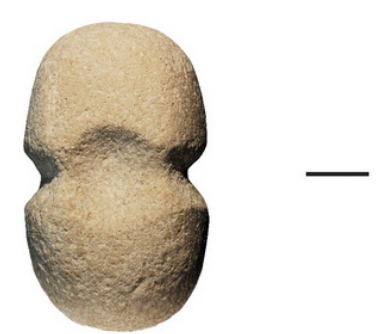

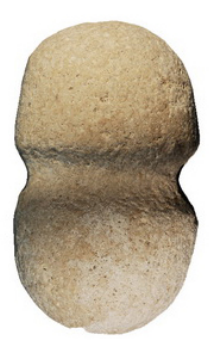

0
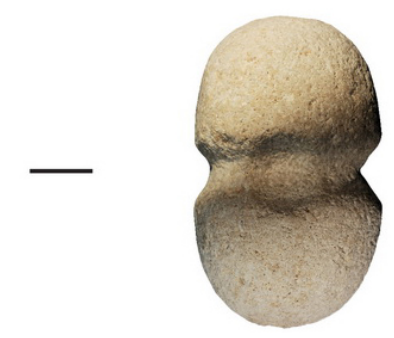

$10 \mathrm{~cm}$

Figure 3. Lithic hammerstone ID 21136 observed in four different views. On its body appears a continuous groove for the hafting and within it two opposed drafted perforations.

\section{Tool ID 9116}

- Typology: lithic hammerstone.

- Context: Tarxien.

- Size: length $10.8 \mathrm{~cm}$; width $9.4 \mathrm{~cm}$; maximum thickness $9 \mathrm{~cm}$.

- Weight: $1194 \mathrm{~g}$.

- Preservation: whole.

- Description: (See Figure 4.) The artefact is made of a light-coloured limestone which encloses an inner part made of a softer rock similar to a slightly darker beige tuff. This tufaceous part crosses the entire body of the tool and reaches the two working surfaces of the implement, which appear slightly chipped. A continuous groove surrounds the median part: it is very deep appearing as a proper gorge (average width $3.25 \mathrm{~cm}$, average depth $1.35 \mathrm{~cm}$ ). The implement shows irregularly ovoid transverse sections. The entire limestone surface shows a dense pecking, which is absent on the tufaceous part.

\section{Tool ID 9115}

- Typology: lithic hammerstone.

- Context: Tarxien.

- Size: length $18.2 \mathrm{~cm}$; width $8.85 \mathrm{~cm}$; maximum thickness $8.75 \mathrm{~cm}$.

- Weight: $1932 \mathrm{~g}$.

- Preservation: almost-whole. 
- Description: (See Figure 5.) A peculiar artefact which typologically belongs to the hammerstone category though it represents a less widespread variant within this category. The groove is wide and deep (average width $3.5 \mathrm{~cm}$, average depth $1.6 \mathrm{~cm}$ ) causing a remarkable narrowing of the lithic body; the two opposed parts of the implement show an almost perfectly globular shape. Its transverse sections are circular. The working surface at one of the two ends was formerly broken; it was restored with chalk integration. A dense pecking can be observed on the entire artefact. No fractures at the points of impact can be identified on the working surface that, on the contrary, appears regular, similar to the other portions of the tool.
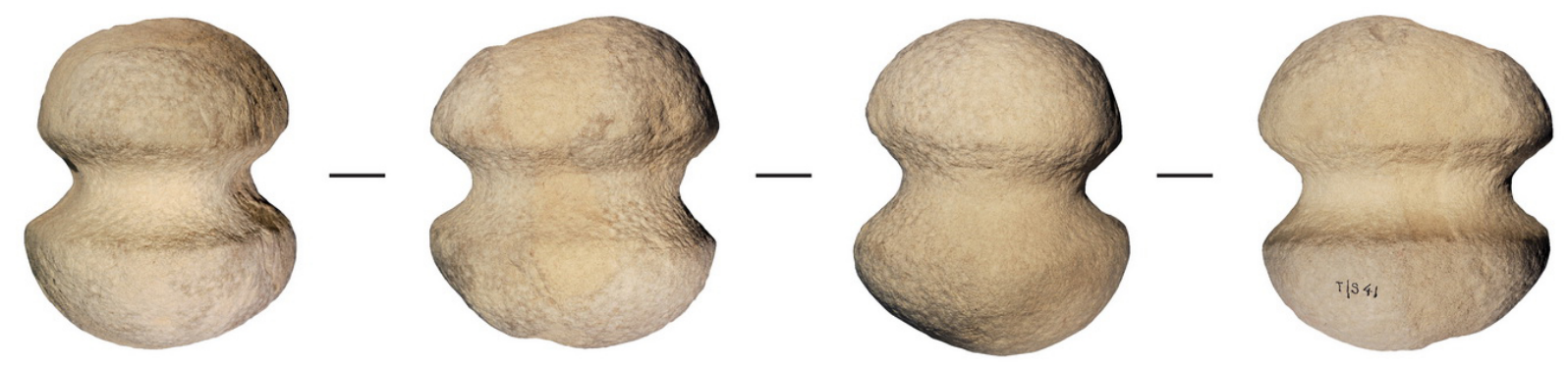

0

$10 \mathrm{~cm}$

Figure 4. Lithic hammerstone ID 9116 observed in four different views. Its characteristic is the deep gorge that surrounds the whole lithic body.
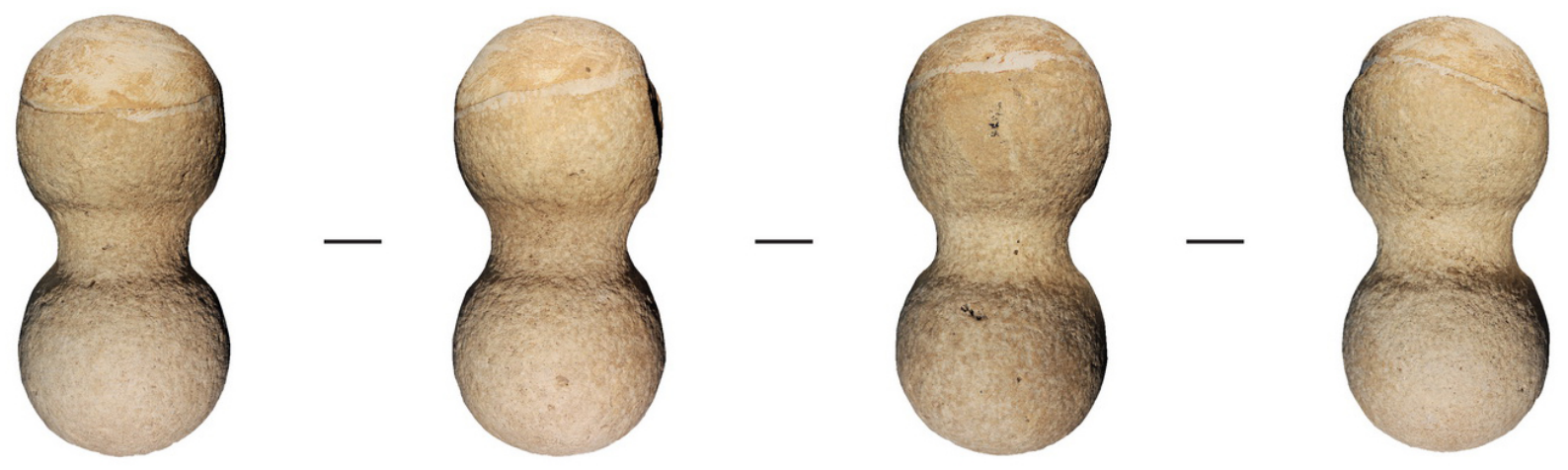

0

$15 \mathrm{~cm}$

Figure 5. Lithic hammerstone ID 9115 observed in four different views. The tool has an uncommon morphology with globular ends and an extremely narrowed central part.

\section{Discussion and conclusion}

These tools reflect the great engineering and crafting abilities of Maltese prehistoric people. Maltese artisans achieved remarkable outcomes with the creation of great megalithic monuments and complex underground structures, often beautifully decorated (Evans 1971; Anati \& Anati 1988: 26-34; Trump 2002; Bonanno 1988: 101-112; Pollini 1988: 133-152). The tools analysed in this paper were involved in heavy and "vigorous" activities which required a specialized toolkit. In particular, the tool ID 9120 (Figure 1) represents a percussion tool of great power, designed and made to strike extremely vigorous blows. We infer that it was used on softer rocks or even, more probably, on wood (e.g., to insert poles and wedges) since the limestone that it was manufactured from is not particularly hard. Studies on Maltese temples building techniques are full of references to the possible use of wooden levers, poles, or wedges. Their use must have necessitated the removal and 
arrangement of lithic blocks, as suggested by semi-circular hollows often found on block surfaces themselves (Bonanno 1988).

These implements could be used to intensify fractures in the rock and detach sections. In order to work properly, wooden levers, piles and wedges had to be struck on their edges by big and powerful percussion tools. From this perspective, tool ID 9120 represents a striking example: it could be handled by two people simultaneously, creating remarkable power of impact (Figure 6).

Scholars have never properly taken into consideration such tools, along with other lithic artefacts such as spheres and rolls used - in the Maltese Islands - to transport huge and heavy lithic boulders from quarries to their final functional destination. This neglect may be the consequence of the high frequency of breakage of large percussion tools, and in many cases might have gone unrecognized as percussion tools. In many cases it is easier to find shapeless fragments and large chips than the whole tool: probably at the end of the work intact tools were carried away in order to be used again. It may be accidental that tool ID 9120 is intact, but there are probably more implements of this type, mostly fragmentary and recognizable only with accurate analysis, to be found in Maltese archaeological excavation warehouses or museum storage rooms.
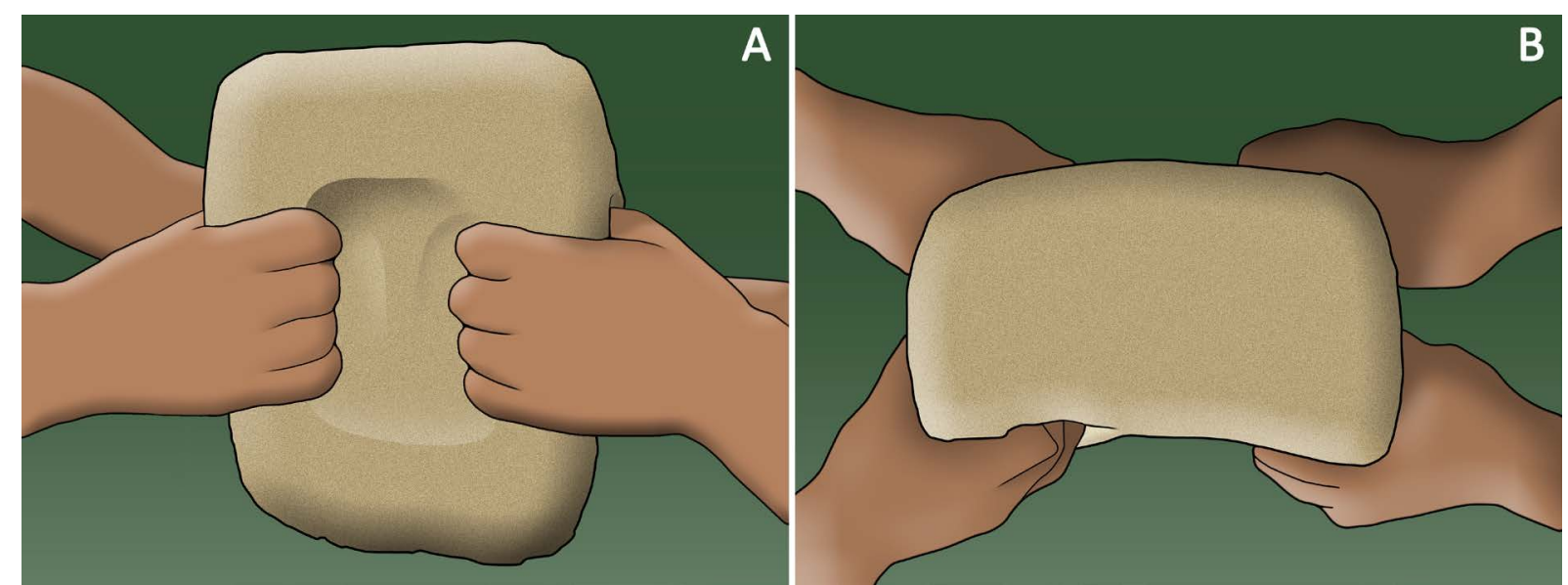

Figure 6. Reconstruction of the use of tool ID 9120, handled by two people at the same time: side view (A) and top view (B). (Graphic reconstruction by F. Breglia.)

On the other hand, the typological variability of the hammerstones (tools ID 21149, 21136, 9116, 9115; Figures 2-5) is interesting. Taking into account that they were found in a restricted territory, their differences might reflect a significant specialization as suggested by the type of hafting methods (single groove, both groove and perforation, very deep groove which can be properly defined a gouge). Different hafting methods are probably linked to different activities. The presence of a depression within the groove leads us to hypothesize two phases of manufacturing. They could be instantly hafted using the groove located on the lithic body; subsequently they could be completed making the perforation through the symmetrical depressions made on the artefact.

It would be interesting to investigate the typological variability of Maltese hammerstones undertaking use-wear analysis on their surfaces (both working and non-working ones) in order to understand their function (what they hit). Unlike the case of querns, pestles, and other stone objects (especially used for grinding), use-wear analysis on grooved hammers are very rare. Research started in Calabria, Italy a few years ago on grooved hammers from various areas of the region pointed out the importance of this type of analysis. Preliminary results from study of the surfaces of about fifty artefacts indicated clear traces of percussion on wood 
and traces of copper ore extraction (personal communication, I. Caricola, Dec. 4, 2015). Hopefully similar research will take place on the Maltese specimens soon.

In this section some examples of similar tools from surrounding areas are presented. Grooved stone tools are widespread in the European countries overlooking the western Mediterranean. These artefacts are generally found in mineral ore rich districts and often represent a proper "guide fossil" for the identification of ancient mining activities (De Pascale 2003; O’Brien 2015: 206-208). The territory of Huelva, in southwest Iberia, is a typical example: hundreds of grooved stone tools linked to the exploitation of underground polymetallic ores were found in several mining sites, from Copper to Late Bronze Age in date (Hunt Ortiz 2003: 281-286).

Likewise, in France, there are several mining areas where similar lithic artefacts were found, Saint-Véran-les-Clausis area in the Haute-Alpes district in particular (Rossi et al. 1997; Barge 2003: 37-38). In the Saint-Véran-les-Clausis territory, properly hafted grooved hammers were used for the bornite supply, an iron and copper sulphide, extracted from the underground since the Copper Age. On the Italian Peninsula and its greater islands it should be noted that, although these artefacts were used for mining activities, they were also used to dig underground cavities for burial, cultic or ritual purposes (the so-called hypogeism phenomenon). This is particularly evident in the case of Sardinia and Sicily. In Sardinia grooved stone tools are very numerous and are found along with other types of lithic percussors, such as maces with central holes, polished or semi-polished, and "flatiron" shaped axes (Figure 7).

These types of tools are chronologically set between advanced Neolithic phases and the Bronze Age, even though in some cases they may persist to the historical ages. Hafting grooves and holes do not coexist on percussors, as can be seen in some of the Maltese specimen presented in this paper. The association between these stone grooved artefacts and Sardinian territories characterized by the so called "domus de janas" (burial structures artificially dug into the rocks) is indicative. Although studies of digging techniques and implements in Sardinia are rather rare, except for a few interesting studies (Giardino 1987; 1995: 140-150), the use of these tools to dig underground structures, such as the over twothousand domus de janas currently known in the region, cannot be excluded with certainty.

In Sicily, on the other hand, grooved stone tools are found on the entire island, but they appear particularly numerous on its eastern side where extraordinary examples of burial complexes artificially dug into vertical rocky walls are located (a well-known example is the protohistoric graveyard of Pantalica, near Siracusa). In the Museo Archeologico Regionale "Paolo Orsi" in Siracusa, there are some examples of grooved percussors of every shape and size: one of these tools is of such a great size and weight (about $10 \mathrm{~kg}$ even if fragmentary) that we would guess that it was used by tying it with rope to a wooden structure and letting it oscillate while hanging so to be thrown against the rock for demolition. Unfortunately these tools are mostly unpublished and, moreover, they often lack a clear indication of their provenance, jeopardizing any exact reconstruction of their use.

A particularly interesting assemblage comes from the so-called "Villaggio Garofalo", in the municipality of Adrano (in Catania area), currently held in the local "Museo Archeologico Regionale" of Adrano. Composed of 20 grooved tools made of lava stone, they range in date from Late Copper Age to Early Bronze Age (Martinelli 2009). The remarkable quantity of such implements in a rather limited spatial context suggests that they are a reflection of various digging activities (perhaps connected to the little artificial caves in lava located near the village or also quarrying works). Unfortunately even in this case we have little information about their archaeological context because they were collected during field survey or through accidental discoveries, as in the case of the Maltese implements; moreover, 
the available documentation about them is often exclusively limited to the generic indication of the provenance location.
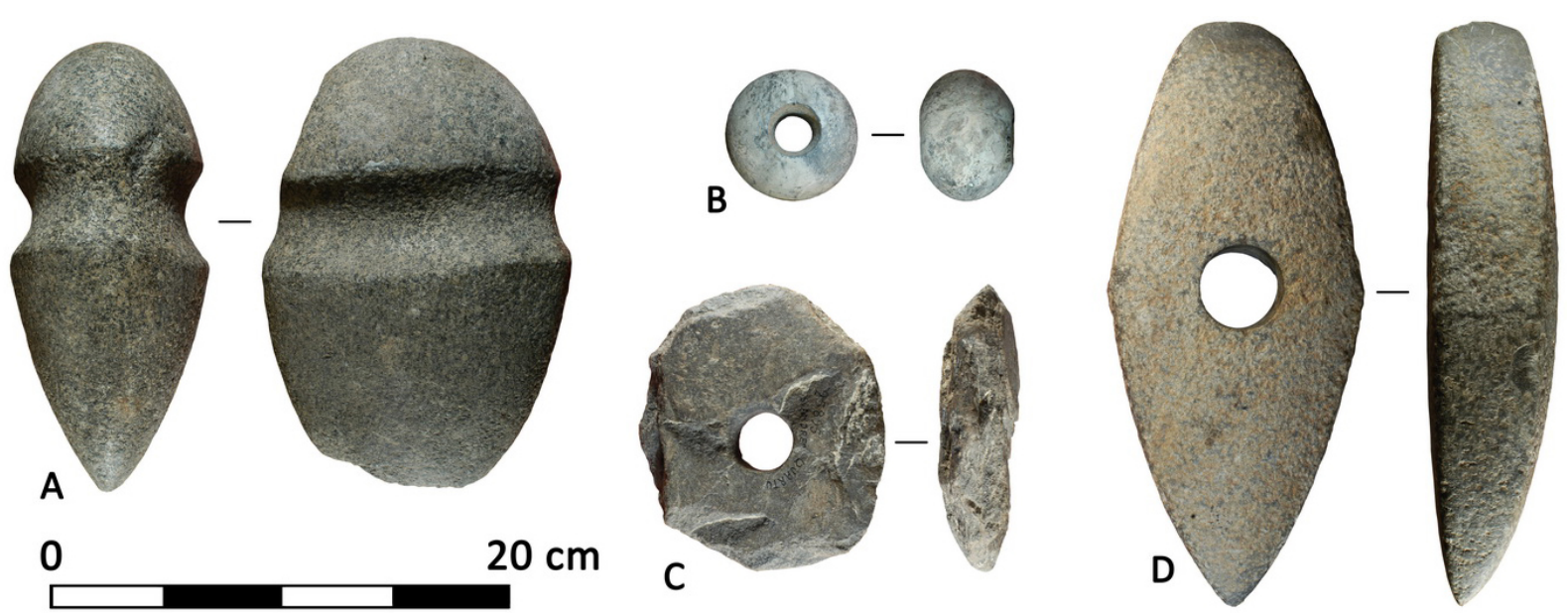

Figure 7. Ground stone percussors found in Sardinia and preserved at the Museo Archeologico Nazionale in Cagliari: grooved hammer-axe (A); maces with central hole (B-C); “flatiron” shaped axe (D). (Photo by F. Larocca.)

As in the cases from Spain and France, also in some Italian regions (Calabria, Liguria and Tuscany) grooved tools are often linked with specific mining activities. The referring chronological time span is late prehistory, from the final phases of the Neolithic up to the subsequent early metal age. Renown sites as Libiola and Monte Loreto in Liguria (Campana et al. 1998; De Pascale 2004; Maggi \& Pearce 2005), or Grotta della Monaca in Calabria (Larocca 2005: 43-47; 2010), show a close relation between these tools and the exploitation of underground mineral sources, especially copper ore.

Concerning the Maltese tools, a mining function should be excluded, since these islands are mainly of calcareous nature and lack any local mining sources. Both in the great architectural complexes (temples and underground structures) and in the small anthropomorphic statuary (Vella Gregory \& Cilia 2005: 36-37), a very frequent use of iron oxides as pigment is reported, but so far there is no evidence that the Maltese grooved tools were involved in the procurement of these ores, inside or outside the islands. It is more likely that these artefacts were used in construction, engineering or craftsmanship, particularly if we bear in mind that in the same areas there are remarkable monuments which surely required skilled stone working.

To date we are unable to determine the precise use of these implements from Malta. Lacking a better understanding of the contexts and, at the same time, waiting for more indepth specialised studies (such as use-wear analysis), we can only assume a generic connection with activities which certainly had to be very common on the Maltese islands. Among these activities, in primis there are quarries for the supply of stone materials to build various kinds of constructions. But certainly we have to consider excavations in the rock in order to create underground structures with several aims: from the small ducts and cisterns, created to collect drinking water, to the deep and articulated underground burial and cultic structures (Steiner \& Vidale 2014).

We can also assume that the tools presented in this paper had multiple functions and had been used - in association with levers - for bedding or lifting stone blocks, for the introduction of poles or wedges in the ground, for finishing works and decoration of stone surfaces with the aid of chisels, through indirect percussion. In conclusion, all these uses may be related to typical construction site activities. 


\section{Acknowledgments}

I would like to express sincere thanks to Dr. S. Sultana, director of the National Museum of Archaeology in Valletta, who allowed the study of the lithic tools examined in the present paper and for the detailed information on the same tools. Heartfelt thanks to Dr. M. De Falco and to Dr. F. Breglia for the English translation and to the latter for the graphic reconstruction of Figure 6.

\section{References}

Anati, A.F., \& Anati, E., (Eds.), 1988, Missione a Malta. Ricerche e Studi Sulla Preistoria dell'Arcipelago Maltese nel Contesto Mediterraneo. Jaca Book, Milano, 241 p. (in Italian) ("Mission at Malta. Researches and studies on the prehistory of Maltese Islands in the Mediterranean context")

Barge, H. 2003, Saint-Véran, la Montagne, le Cuivre et l'Homme. I. Mine et Métallurgie Préhistoriques dans les Hautes-Alpes. Actilia Multimédia, Theix, 85 p. (in French) ("Saint-Véran, mountain, copper and man. I. Prehistoric mine and metallurgy in the Hautes-Alpes”)

Bonanno, A. 1988, Tecniche costruttive dei templi megalitici maltesi. In: Missione a Malta. Ricerche e Studi Sulla Preistoria dell'Arcipelago Maltese nel Contesto Mediterraneo (Anati, A.F., \& Anati, E., Eds.), Jaca Book, Milano: p. 101-111. (in Italian) (“Building techniques of maltese megalithic temples")

Campana, N., Maggi, R., \& Pearce, M. 1998, Libiola e Monte Loreto: due miniere di rame preistoriche nella Liguria orientale. In: Le scienze della Terra e l'Archeometria (Atti della IV Giornata, Istituto Universitario Suor Orsola Benincasa, Napoli, 20-21 febbraio 1997) (D’Amico, C., \& Albore Livadie, C., Eds.), Editore Cuen, Naples: p. 175-179. (in Italian) ("Libiola and Monte Loreto: two prehistoric copper mines in the eastern Liguria”)

Evans, J.D. 1971, The Prehistoric Antiquities of the Maltese Islands: a Survey. Athlone Press, London, $260 \mathrm{p}$.

Hunt Ortiz, M.A. 2003, Prehistoric Mining and Metallurgy in South West Iberian Peninsula, BAR International Series Vol. 1188, Archaeopress, Oxford, 418 p.

Giardino, C. 1987, Sfruttamento minerario e metallurgia nella Sardegna protostorica. In: Studies in Sardinian Archaeology. III. Nuragic Sardinia and the Mycenaean World (Balmuth, M.S., Ed.), BAR International Series Vol. 387, Archaeopress, Oxford: p. 189-222. (in Italian) ("Mining exploitation and metallurgy in protohistoric Sardinia”)

Giardino, C. 1995, The West Mediterranean Between the 14th and 8th Centuries B.C. Mining and Metallurgical Spheres, BAR International Series Vol. 612, Archaeopress, Oxford, $410 \mathrm{p}$.

Larocca, F., (Ed.), 2005, La Miniera Pre-Protostorica di Grotta della Monaca (Sant'Agata di Esaro - Cosenza), Università degli Studi di Bari \& Centro Regionale di Speleologia "Enzo dei Medici”, Roseto Capo Spulico, 98 p. (in Italian) (“The pre-protohistoric mine of Grotta della Monaca (Sant’Agata di Esaro - Cosenza)”) 
Larocca, F. 2010, Grotta della Monaca: a prehistoric copper and iron mine in the Calabria region (Italy). In: Mining in European History and its Impact on Environment and Human Societies; Proceedings for the $1^{\text {st }}$ Mining in European History-Conference of the SFB-HIMAT, November 12-15 2009, Innsbruck (Anreiter P., Goldenberg, G., Hanke, K., Krause, R., Leitner, W., Mathis, F., Nicolussi, K., Oeggl, K., Pernicka, E., Prast, M., Schibler, J., Schneider, I., Stadler, H., Stöllner, T., Tomedi, G., Tropper, P., Eds.), Innsbruck University Press, Innsbruck: p. 267-270.

Maggi, R., \& Pearce, M. 2005, Mid fourth-millennium copper mining in Liguria, North-West Italy: the earliest known copper mines in Western Europe. Antiquity, 79(303): 66-77. doi:10.1017/S0003598X00113705

Martinelli, M.C. 2009, Le asce martello e altri manufatti in pietra levigata conservati nel Museo di Adrano. In: Tra Etna e Simeto. La Ricerca Archeologica ad Adrano e nel Suo Territorio (Lamagna, G., Ed.), Biblioteca della Provincia Regionale di Catania, Catania: p. 69-74. (in Italian) ("Hammeraxes and other ground stone artifatc kept in the Museum of Adrano")

O’Brien, W. 2015, Prehistoric Copper Mining in Europe. 5500-500 BC. Oxford University Press, Oxford, 345 p.

De Pascale, A. 2003, “Hammerstones from Early Copper mines”: Sintesi dei ritrovamenti nell'Europa e nel Mediterraneo orientale e prime considerazioni sui mazzuoli di Monte Loreto (IV millennio BC - Liguria). Rivista di Studi Liguri, 69: p. 5-42. (in Italian) ("Hammerstones from Early Copper Mines: A synthesis of the findings in Europe and eastern Mediterranean and first observations on Monte Loreto's hammerstones ( $4^{\text {th }}$ millennium BCE - Liguria)”)

De Pascale, A. 2004, Studio preliminare dei mazzuoli litici della miniera preistorica di Monte Loreto: analisi formale e classificazione. In: Metodi e Pratica della Cultura Materiale. Produzione e Consumo dei Manufatti (Giannichedda, E., Ed.), Istituto Internazionale di Studi Liguri, Bordighera: p. 53-58. (in Italian) ("Preliminary study on the hammerstones from the prehistoric mine of Monte Loreto: formal analysis and classification”)

Rossi, M., Rostan, P., \& Gattiglia, A. 1997, Una miniera di rame preistorica nelle Alpi Occidentali. Le Scienze, 58(344): 74-80. (in Italian) (“A prehistoric copper mine in the Western Alps")

Steiner, A.M., \& Vidale, M. 2014, Nelle isole dei templi giganti. Archeo, 353: 62-93. (in Italian) ("In the islands of giant temples")

Sultana, S. 2006, The National Museum of Archaeology. Valletta. The Neolithic Period. Heritage Books, Valletta, 48 p.

Trump, D.H. 2002, Malta: Prehistory and Temples. Midsea Books Ltd., Valletta, 320 p.

Vella Gregory, I., \& Cilia, D. 2005, The Human Form in Neolithic Malta. Midsea Books Ltd., Valletta, $200 \mathrm{p}$. 